\title{
A multi-method approach to groundwater risk assessment: a case study of a landfill in southern Poland
}

\author{
Marek SOŁTYSIAK ${ }^{1}$, Dominika DAZBROWSKA ${ }^{1, *}{ }^{*}$, Konrad JAŁOWIECKI ${ }^{2}$ \\ and Vahid NOURAN1, 4 \\ 1 University of Silesia, Faculty of Earth Sciences, Będzińska 60, 41-200 Sosnowiec, Poland \\ 2 University of Silesia, Faculty of Mathematics, Physics and Chemistry, Bankowa 14, 40-007 Katowice, Poland \\ 3 University of Tabriz, Faculty of Civil Engineering, Department of Water Resources Engineering , P.O. Box: 51666, \\ Tabriz, Iran \\ 4 Near East University, Department of Civil Engineering, P.O. Box: 99138, Nicosia, North Cyprus
}

Sołtysiak, M., Dabrowska, D., Jałowiecki, K., Nourani, V., 2018. A multi-method approach to groundwater risk assessment: a case study of a landfill in southern Poland. Geological Quarterly, 62 (2): 361-374, doi: 10.7306/gq.1411

\begin{abstract}
Estimating groundwater vulnerability to pollution is based on the quantitative and qualitative assessment of the degree of exposure to the pollution. This article attempts to assess groundwater vulnerability to pollution in the area of a complex of landfill sites located in the supply area of one of the important groundwater reservoirs in southern Poland. Two dynamic leaching tests and two static tests were carried out on two different samples of slag from one of the metallurgical landfills during various periods of storage (15 year old waste and freshly deposited waste). Transport equations were based on the data from a column experiment. The advection-dispersion equation for column leaching was employed, which confirmed the simulation parameters through experimentation. The results of the leaching tests on chlorides showed that they are leached from the landfill over a period of $\sim 60-90$ years from the moment of depositing the waste. The seepage time for the Quaternary aquifer is 1-7 years and, for the Triassic aquifer, 5-40 years. The Backman's contamination index (1998) values exceeded 25, while a high threat to groundwater is observed when the contamination index value equals 3 . The use of all the aforementioned methods determined the most vulnerable area.
\end{abstract}

Key words: vulnerability, leaching tests, contamination index, landfills.

\section{INTRODUCTION}

The term "groundwater vulnerability to contamination" has been applied since the 1960s (Witkowski and Kowalczyk, 2004; Hermanowski and Ignaszak, 2017). There are two types of vulnerability: intrinsic and specific. According to the definition, intrinsic vulnerability is the property of an aquifer system that determines the risk of the migration of contaminants from the land surface to the groundwater, which is entirely dependent on the geological structure and hydrogeological conditions (Krogulec, 2004). Specific vulnerability, alongside the natural properties of the aquifer system, takes into account the pressure on the environment resulting from human activity; therefore, this type of vulnerability is determined predominantly in industrialized areas (Gogu and Dassargues, 2000; Krogulec, 2011).

There is a number of methods enabling the assessment of groundwater vulnerability to contamination (Vrba and Zaporozec, 1994; Zwahlen, 2004; Civita, 2010; Wachniew et al.,

* Corresponding author, e-mail: ddabrowska@us.edu.pl Received: July 7, 2017; accepted: December 28, 2017; first published online: May 8, 2018
2016), including estimation methods, parameter methods (Goldscheider, 2003; Kabbour et al., 2006; Oke et al., 2016; Hermanowski and Ignaszak, 2017), ranking methods (Foster, 1987), methods of mathematical and hydrogeochemical modelling (Witkowski et al., 2003), tracer methods (Leibundgut et al., 2009), artificial neural networks (Nourani et al., 2011, 2013, $2017 a, b)$, hydrochemical methods, and statistical and geostatistical methods (Troiano et al., 1999; Lambrakis et al., 2004; Panagopoulos et al., 2006; Bhuiyan et al., 2016).

The assessment of groundwater vulnerability to contamination is particularly important in the case of highly industrialized areas, wherein there are potential and actual sources of pollution, such as landfills, incinerators, coking plants or smelting plants (Zhang et al., 2009). Nevertheless, the subject of groundwater vulnerability in areas heavily transformed by industrial activities, in relative terms, is rarely investigated because of the difficulty in assessing unequivocally the degree of threat to the soil and water environment, and evaluating the factors presenting this threat.

So far, several proposals have been made to undertake an assessment of groundwater vulnerability to contamination in areas used for agricultural purposes (Yang and Wang, 2010; Boufekane and Saighi, 2013) and in mining areas (Witkowski et al., 2003). 
Groundwater contamination is a particularly significant problem in the area of landfills. Hence, the groundwater protection in the landfill area is essential for rational water management (Robins et al., 1998; Gomo and Masemola, 2016). One of the methods used to determine the degree of transformation in chemical composition is by calculating the Backman's contamination index. This measure allows for the possibility of assessing comprehensively both spatial and temporal changes in pollution on the basis of a single cumulative index, as well as partial indices for individual parameters.

Considering the individual approach to groundwater vulnerability assessment, which is often at an excessively high level of generality, a multi-aspect method, involving dynamic and static leaching tests, the modelling of breakthrough curves for chloride ions, the calculation of vertical seepage time, and the determination of the groundwater contamination index, was performed. Using different methods to address the problem of groundwater vulnerability is extremely important for a highly urbanized area, as single methods cannot provide credible assessments.

The focus of the research is based on the supply area of one of the important groundwater reservoirs in which, in the 1970s, without considering the principles of protecting the land and water environment, an industrial zone with developed infrastructure was unfortunately located. This paper concerns research on the results of waste samples taken from an unsealed metallurgical landfill with an area of 40 ha.

\section{STUDY AREA}

The study area is located to the east of Strzemieszyce Małe, which is part of Dabrowa Górnicza (southern Poland) and covers an area of approximately $10 \mathrm{~km}^{2}$. In this region, there is a complex of industrial objects, which comprises a waste landfill for the Dabrowa Górnicza branch of the ArcelorMittal Poland smelting plant (formerly Huta Katowice) in Lipówka, a dormant landfill in Zakawie, a municipal landfill (Lipówka I and Lipówka II), the Przyjaźń coking plant, including its waste landfill, and the SARPI waste incinerator (Fig. 1).

The Lipówka landfill for smelting plant waste and the Zakawie landfill were constructed directly on natural land without any prior protection of the ground. The other aforementioned landfill sites were isolated from the ground. The substratum of the SARPI incinerator was also protected. In the Przyjaźń coking plant area, there is only a liner system preventing the ground from leachate.

\section{GEOLOGICAL SETTINGS AND HYDROGEOLOGICAL CONDITIONS}

The complex of landfills is located in the northeastern part of the Upper Silesian Coal Basin within the Blędów Basin (Stupnicka, 2007). In the subsurface of the research area, Triassic and Quaternary formations are of crucial importance. The Triassic is represented by the Lower and Middle Buntsandstein, Roet, and locally Muschelkalk sediments. The Buntsandstein is represented by conglomerates, sands, sandstones, siltstones and claystones. In this area, the Roet is bipartite with dolomitic marls, marly dolomites and marly limestones in the bottom. The upper part of the Roet consists of bedded dolomites and lime- stones (Alexandrowicz and Alexandrowicz, 1960). The Muschelkalk is composed of carbonates: Gogolin beds, ore-bearing dolomites and Diplopora dolomite. The Quaternary sediments occur only in terrain depressions, lying on the Triassic carbonates or Buntsandstein siltstones. The Quaternary is represented by silt, clay and sand in this region.

The Strzemieszyce region is covered by glacial tills of the South Polish Glaciation, and glaciofluvial sands and gravels deposited during the Middle Polish Glaciation. There is rock waste in the area of outcrops with a thickness of up to several metres.

In the area of the analysed complex of landfills, there are two water-bearing layers: Quaternary and Triassic aquifers (Fig. 2). The Quaternary water-bearing layer is characterized by a variable thickness and a lack of continuity. This aquifer is associated with fluvioglacial sands and sand and gravel alluvia occurring in the valleys. The thickness of the aquifer does not exceed $6 \mathrm{~m}$. The general groundwater flow direction within the Quaternary aquifer is southerly or south-westerly. The aquifer is recharged directly by infiltrating water from precipitation without any natural isolation. The hydraulic conductivity value varies from $7.1 \cdot 10^{-6}$ to $4.3 \cdot 10^{-5}$. The groundwater tables of the Quaternary aquifer are either unconfined or locally confined, and occur at small depths of a few metres. The industrial area of Strzemieszyce Małe is located in the recharge area of the Olkusz-Zawiercie karst-fissured Triassic aquifer, which is one of the major sources of notable water for the Upper Silesian agglomeration.

The Triassic aquifer comprises Muschelkalk, Roet and Buntsandstein water levels. The first two levels form a water-bearing complex of the Triassic carbonates (Róźkowski et al., 1997). This aquifer is composed of dolomites and limestones that represent a karst-pore-fissure type (Różkowski, 1990). In the landfill area, the main aquifer is of Roet type (Figs. 1 and 2). The thickness of this aquifer is up to $20 \mathrm{~m}$, while the hydraulic conductivity value is in the range of $1.57 \cdot 10^{-4}-3.31$. $10^{-4} \mathrm{~m} / \mathrm{s}$. The water table is predominantly unconfined.

Owing to the presence of the outcrops of Triassic carbonates, the study area is characterized by high and very high vulnerability of the groundwater to contamination (Bielewicz et al., 2010). Numerous industrial objects located in this area, among others, coking plants, waste incinerators and the complex of landfills, pose a high degree of environmental risk.

\section{GROUNDWATER MONITORING NETWORK}

There are 37 boreholes with piezometers operating within local groundwater monitoring networks (LGMNs) (Fig. 2).

The study area is covered by five LGMNs that belong to the Przyjaźń coking plant, the industrial waste landfill of the ArcelorMittal smelting plant, two municipal waste landfills, and the SARPI incinerator. The oldest network monitors the environmental impact of the Lipówka smelting plant's waste landfill. This network was created between 1988 and 1994, and consists of 14 piezometers. In 1993, another observation network was created around the Zakawie waste landfill (PQ16, PQ17, PT11 and PT12), although it is not currently operational (Fig. 1).

The groundwater around the municipal landfill of Lipówka II is monitored by piezometers PZ1, PZ2, PZ3, PZ4 and PZ5 (Fig. 1 ), the last two of which also monitor the water around the landfill of Lipówka I. The monitoring around the waste landfill of the Przyjaźn coking plant is conducted on the basis of four piezometers (P1, P2, P3, P4) (Fig. 1). In the coking plant area, 


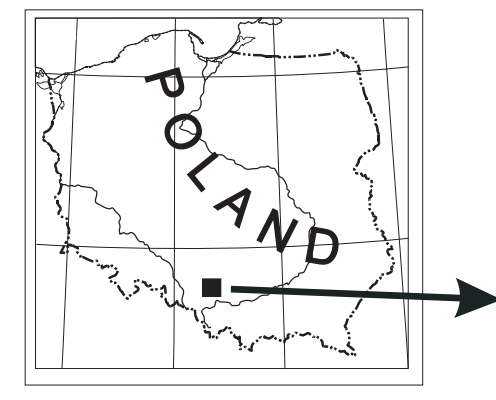

piezometers in the Triassic

$\triangle$ piezometers in the Quaternary
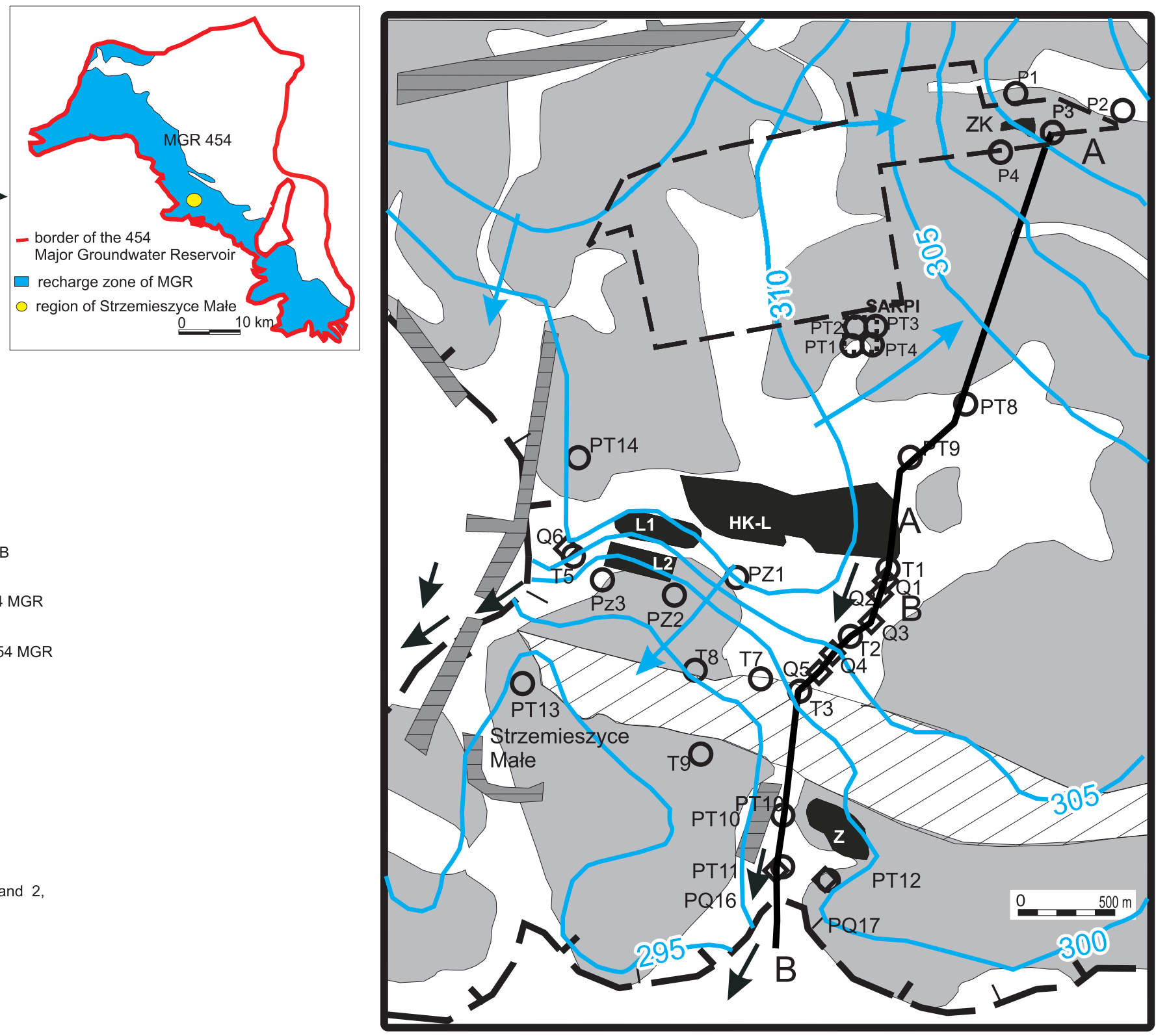
B

$\mathrm{S}$

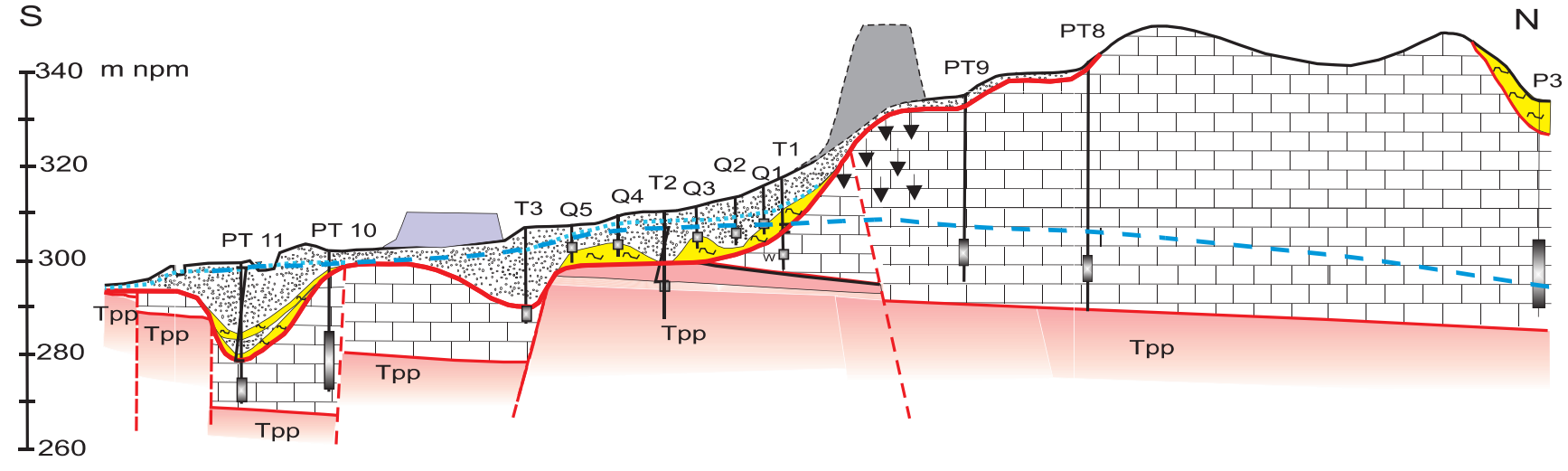

N

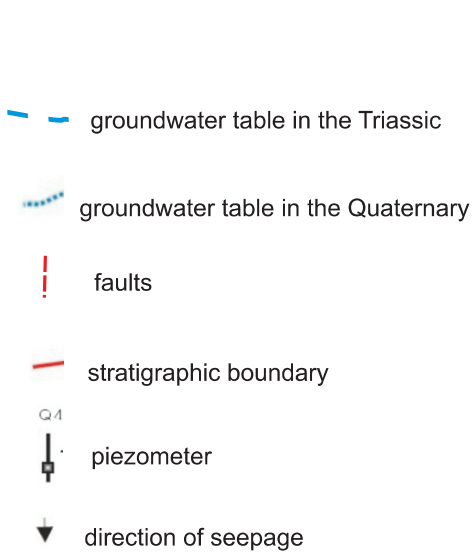

Z confined water table
Lipówka landfill

railway embankment

permeable Quaternary

sediments: mainly sands

poorly permeable Quaternary

sediments: loam and silt

Triassic carbonate rocks:

dolomite, limestone

Lower and Middle Buntsandstein deposits: clay, sand, sandstone

Fig. 2. Hydrogeological cross-section A-B through the study area

an additional three piezometers have been installed; however, they are not utilized. Since 2002, the SARPI waste incinerator has utilized an observation network, initially consisting of two piezometers, but has since been increased to four.

\section{METHODOLOGY}

To determine the threat to the groundwater of the Quaternary and Triassic aquifers in the study area, generated by the landfill of slags, the following laboratory and calculation methods have been employed: chemical analyses of metallurgical slags, batch and column tests, and modelling of leaching time. Two samples representing the various types of steel waste were tested. In relation to the whole area, calculations of the time of vertical seepage and the determination of the contamination index were carried out. The results of the study have been confronted with and confirmed by the results of the groundwater monitoring research conducted for landfills (Fig. 3).

Our assessment of groundwater vulnerability to pollution was based on estimation of the seepage time through the unsaturated zone. Chlorides are not subject to sorption processes, thus they reflect the resistance time of water in the system. With this in mind, only the results of the leaching tests obtained for chlorides were taken into account.

\section{THE COLUMN TESTS}

The purpose of the dynamic leaching tests is to determine, under laboratory conditions, the loads of the pollution that leaches out of the tested material. Dynamic leaching tests consist of administering a solution (which is usually distilled water) to a column filled with the tested soil. The amount of liquid entering the column simulates the amount of precipitation. Once the solution has flown through the column, the chemical composition of the effluent solution is determined (Brown and Donnelly, 2009). The dynamic method allows for the determination of the parameters of mass transfer (sorption, leaching, dissolution of the substance), and the parameters of convective transfer and hydrodynamic dispersion (Priddle and Jackson, 1991; Sołtysiak, 2007).

Dynamic leaching tests were carried out on two samples of the smelting plant waste: the first was 15 years old and taken from an excavation undertaken at the base of a $20 \mathrm{~m}$ high slope of the landfill, while the second was only a few days old (hereinafter referred to as fresh waste), obtained from material freshly deposited in the landfill (Soltysiak, 2009). Leaching tests were performed using flow cells with an inner diameter of $11.4 \mathrm{~cm}$ and a height of $9 \mathrm{~cm}$ for the 15 year old precipitation, and $10.5 \mathrm{~cm}$ for the fresh waste, supplied by an infusion pump. The performance of the infusion pump was calculated on the basis of the average precipitation of the multi-year period of 

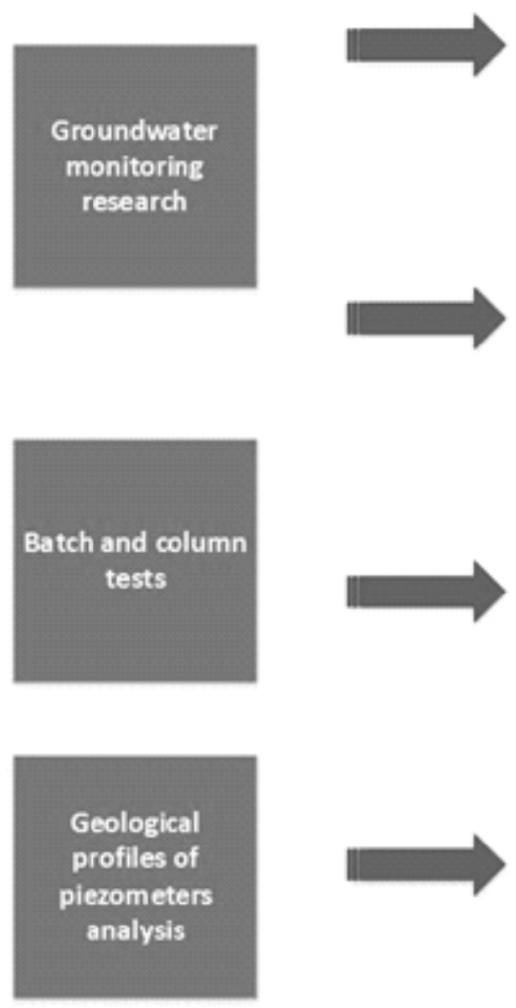

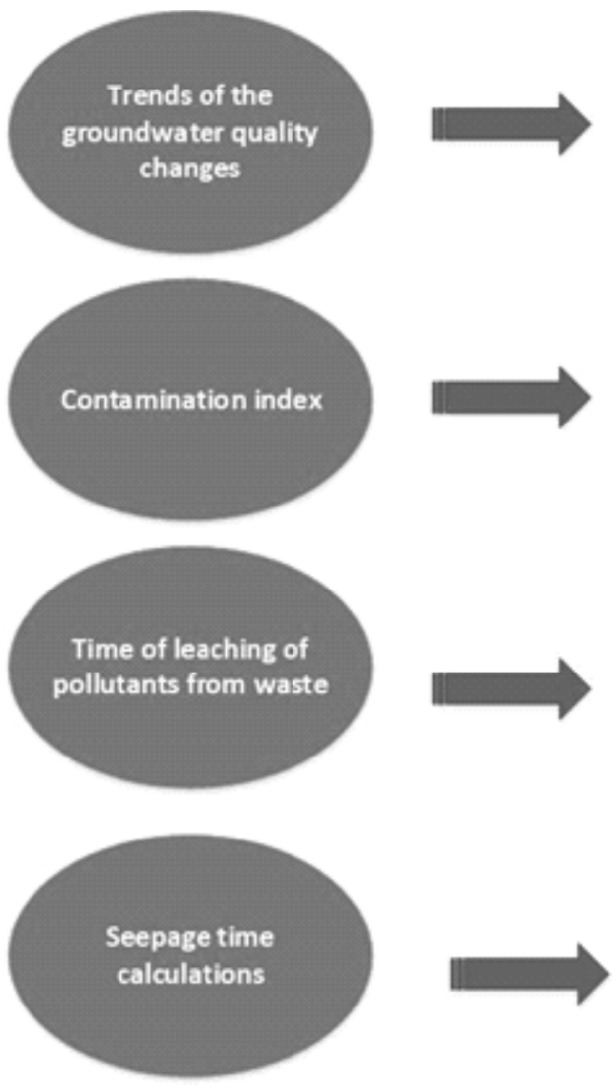

Fig. 3. The schematic of proposed methods

1975-2000 for Zabkowice, Bolesław and Katowice, which amounted to $744.5 \mathrm{~mm}$, and an assumed effective infiltration coefficient of 0.3 . The assumption was based on the results of lysimetric studies, which, for similar poorly compacted waste samples, showed an infiltration rate of $47-49 \%$ (Sołtysiak, 2007). To account for the impact of compaction, the value of the effective infiltration coefficient was reduced to 0.3 , which should be used in relation to natural sands and gravels (Pazdro, 1983). The waste was characterized by a gravelly and sandy fraction. At these rates, the supply from the pump, simulating the supply under natural conditions, amounted to $6.24 \mathrm{~cm}^{3} / \mathrm{d}$. The leachate samples were collected at intervals of 8-12 days. A total of 10 leachate samples were collected from the old waste (six $50 \mathrm{~cm}^{3}$ samples and four $75 \mathrm{~cm}^{3}$ samples) and a total of 15 samples were collected from the fresh waste (11 samples of $50 \mathrm{~cm}^{3}$ and four $75 \mathrm{~cm}^{3}$ samples), in which the chloride concentration was determined using the titration method. In the case of the 15 year old sample, an experiment was conducted until the concentration of $\mathrm{Cl}$ was at the lower limit of quantitation, while, in the case of a fresh sample, the experiment was conducted until the concentration of $\mathrm{Cl}$ was halved.

\section{THE BATCH TESTS}

Batch tests involve allowing the sample to come into contact with a liquid for a limited time, followed by conducting a physical and chemical analysis of the liquid to determine the type and amount of substances that leached out of the sample. Batch leaching tests are used to characterize materials subjected to leaching and the type and quantity of leached substances. They provide a quick and easy way of acquiring infor- mation about possible pollutants leaching from the waste into the environment.

A static method consists of triggering the reaction between the tested soil and the liquid in a closed vessel. The methodology of conducting the test is vital, especially the type of leaching liquid, its amount in relation to the solid phase, and the amount of time that the liquid was in contact with the tested sample. On this basis, the initial weight of the chlorides contained in the samples of the soil subjected to dynamic testing was determined.

The batch tests were conducted according to European Standard EN 12457-2, at a liquid-to-solid ratio of 10:1 l/kg.

\section{GROUNDWATER FLOW MODELLING}

To interpret the results of the column test, the one-dimensional (1D) transport equation was used. As the concentration of the chlorides that leached from the column was measured from the leachate, the interpretation was made by using the advection-dispersion equation in the form:

$$
C(x, t)=\frac{M}{Q} \frac{x}{\sqrt{4 \pi D_{L} t^{3}}} \exp \left[-\frac{(x-v t)^{2}}{4 D_{L} t}\right]
$$

which is the solution of the 1D transport equation. It was assumed, as in a tracer experiment, that the tracer was injected at $x=0$ into the water flowing into the column and measured as the flux-averaged concentration (Zuber, 1984; Liu et al., 2004). As the tracer was injected instantaneously, the boundary conditions were as follows: 
Table 1

The hydraulic properties of soils (Fetter, 2001; Todd and Mays, 2005; Wang et al., 2014)

\begin{tabular}{|l|c|c|c|}
\hline \multicolumn{1}{|c|}{ Lithology } & $\mathrm{w}_{\mathrm{o}}$ & $\mathrm{n}_{\mathrm{e}}$ & $\mathrm{k}^{\prime}(\mathrm{m} / \mathrm{s})$ \\
\hline $\begin{array}{l}\text { Loamy sands, sandy } \\
\text { loams }\end{array}$ & 0.1 & 0.10 & $10^{-9}-10^{-8}$ \\
\hline Sands, fine sands, rubble & 0.1 & 0.25 & $2 \cdot 10^{-8}-10^{-5}$ \\
\hline Clays, sandy clays & 0.24 & $0.05-0.015$ & $10^{-12}-4.7 \cdot 10^{-10}$ \\
\hline Silts & 0.28 & 0.025 & $10^{-10}-2 \cdot 10^{-6}$ \\
\hline Marls & 0.02 & 0.005 & $10^{-8}$ \\
\hline Limestones and dolomites & 0.02 & 0.04 & $10^{-7}-10^{-10}$ \\
\hline Loams, silt loams & 0.35 & 0.01 & $10^{-8}$ \\
\hline
\end{tabular}

$w_{o}$ - volumetric water content; $n_{e}$ - effective porosity; $k^{\prime}$ - vertical hydraulic conductivity

$$
\lim C(x, t)=0
$$

where: $M$ - mass of the chlorides (mg Cl/kg d.m.); $D_{L}$ - coefficient of longitudinal dispersion $\left(\mathrm{cm}^{2} / \mathrm{d}\right) ; \mathrm{Q}$ - volumetric flow rate through the column $\left(\mathrm{cm}^{3} / \mathrm{d}\right) ; v$ - mean water velocity $(\mathrm{cm} / \mathrm{d}) ; \mathrm{x}$ - dimensional space $(\mathrm{cm}) ; t$ - time $(\mathrm{d})$.

The values of parameters $v$ and $D_{L}$ were calculated from experimental data obtained from the outflow. While constructing the model, the estimation of the dispersion parameter was carried out. The construction of the model assumes that the volumes of the liquid flowing from the column in each time unit are almost identical. On this assumption, the experimentally obtained value of chlorides concentration in the leachate, which was collected from time $t_{1}$ to time $t_{2}$, should be close to the average value of the function of chlorides concentration in the output $C(t)$ within the interval $\left[t_{1}, t_{2}\right]$, that is, the integral:

$$
\frac{1}{t_{1}-t_{2} \int_{t_{1}}^{t_{2}} C(t) d t}
$$

Assuming that $y_{1}, \ldots y_{n}$ represent experimentally measured values for the times $t_{1}, \ldots, t_{n}$, then the estimation of the $D_{L}$ parameter is carried out by minimizing the total of the squared differences between the values of $y_{i}$ and the predicted values in Formula [2], i.e., by minimizing the function:

$$
f\left(D_{L}\right)=\sum_{i=1}^{N}\left(y_{i}-\frac{1}{t_{1}-t_{i-1}} \int_{t_{i-1}}^{t_{1}} C(t) d t\right)^{2}
$$

where: $t_{0}$ - given the value of 0 .

The minimization was performed using the L-BFGS-B method (Zhu et al., 1997). The L-BFGS is a modification of the original BFGS method as it improves the former's memory complexity. Instead of using a dense Hessian matrix, L-BFGS stores only its approximation, resulting in linear memory complexity (in terms of a number of variables) instead of quadratic complexity. The L-BFGS method is capable of solving minimization problems with unconstrained variables only, which is why we used the L-BFGS-B variant to allow for the imposition of box constraints. This is done by identifying, in each step, the set of fixed variables and using L-BFGS with free variables to improve the accuracy of the solution. The obtained results of the dynamic tests were utilized for modelling, aided by the employment of our own program written in the Python programming language. The program performed the minimization of function as described in [3], using highly performant numerical packages available for Python, including NumPy and SciPy. In particular, we used the scipy.optimize module and its minimization function as an interface with the L-BFGS-B solver.

The calculations enabled the modelling of the chlorides concentration variability over time. This was very important in the case of the experiment with freshly deposited waste. Before the leachate collection started, waste samples were fully saturated. As a result, it was possible to relate the modelling results to the body of the Lipówka landfill of smelting plant waste.

\section{VERTICAL SEEPAGE TIME}

After that, based on well logs, an attempt was made to determine the groundwater vulnerability of the Triassic carbonate series. The basis for this assessment was the estimation of the time of the vertical seepage of potential contaminants from the surface to the studied aquifer, assuming a simple piston-flow model.

Calculating the time of vertical seepage is significant in terms of the analysis of water quality changes. Assuming the negative impact of the analysed object on the groundwater quality, it is expected that the potential contamination will reach the water table within a time equal to or longer than that of vertical seepage. The lag time in reaching the groundwater table by the contaminants is mainly due to sorption processes. Given that the intensity of sorption depends on, inter alia, the properties of the sorbent, as well as the simplified nature of the formulas determining the time of vertical seepage, the obtained results should be regarded as approximate.

The time of seepage $t_{v s}$ through the unsaturated zone was determined in accordance with Formula [4], as proposed by Bachmat and Collin (Witczak and Żurek, 1994):

$$
t_{v s}=\frac{m \cdot w_{0}}{R}
$$

where: $m$ - thickness $(\mathrm{m}) ; w_{o}$ - volumetric water content $(\%$; see Table 1); $R$ - effective infiltration ( $\mathrm{m} / \mathrm{a})$.

In the case of the water table in the water-bearing formations of the Quaternary aquifer, the time of seepage $t_{v s}$ ' into the formations of the aquifer complex of the Triassic carbonate series was estimated on the basis of Formula [5] for the flow rate:

$$
t_{v s}=\frac{m^{2} \cdot n_{e}}{k \cdot \Delta \mathrm{H}}
$$

where: $n_{e}$ - effective porosity; $k^{\prime}$ - vertical hydraulic conductivity; $\Delta \mathrm{H}$ - difference in the pressure between the water table of the Quaternary aquifer and the water table of the water-bearing complex of the carbonate series.

The total of the times $t_{v s}$ and $t_{v s}$ ' was assumed as the final value of the seepage time. 


\section{CONTAMINATION INDEX}

To assess the degree of groundwater contamination in the area of the studied objects, the contamination index was employed (Backman et al., 1998; Singh et al., 2015). The index was calculated on the basis of monitoring research conducted in the vicinity of the complex of landfills. This measure determines the amount of groundwater contamination in relation to the natural hydrogeochemical background. The contamination index was calculated using Formula [6] (Backman et al., 1998), as follows:

$$
C_{d}=\sum_{i=1}^{n} C_{f i}
$$

where:

$$
C_{f i}=\frac{C_{A i}}{C_{N i}}-1
$$

where: $C_{f i}$ - contamination factor for the i-th component; $C_{A i}-$ analytical value of the i-th component; $C_{N i}$ - upper range of natural hydrogeochemical background.

This index was calculated separately for each of the analysed water samples in order to determine the total of the contaminants of the individual components exceeding the upper value of the background. Along with an increase in the concentration of a given component in relation to the natural hydrogeochemical background, the contamination index value grew.

It was assumed that the threat to groundwater is high in an area where the index value is $>3$, whereas it is low when the index value is $<1$. The hydrogeochemical background values of Triassic carbonate series were taken from Różkowska et al. (1975), based on the data from the 1960s, that is, before large industrial plants were established in this area. A set of analyses of the chemical composition of groundwater from the Blędów Basin region, in which the study area is located, was collated. It involved 143 analyses.

\section{RESULTS}

The obtained results of the tests on leaching chlorides from the 15 year old waste are presented in Table 2. The chlorides

Table 2

Chlorides concentration in a dynamic leaching test for the 15 year old waste

\begin{tabular}{|c|c|c|}
\hline Sampling day & $\begin{array}{c}\text { Sample volume } \\
{\left[\mathrm{cm}^{3}\right]}\end{array}$ & $\begin{array}{c}\text { Chlorides concentration } \\
{\left[\mathrm{mg} / \mathrm{dm}^{3}\right]}\end{array}$ \\
\hline 8 & 50 & 53 \\
\hline 16 & 50 & 42.54 \\
\hline 24 & 50 & 35.45 \\
\hline 32 & 50 & 22.7 \\
\hline 40 & 50 & 17 \\
\hline 48 & 50 & 11.3 \\
\hline 60 & 75 & 9.2 \\
\hline
\end{tabular}

The results of the tests of leaching chlorides from the fresh waste are presented in Table 3

T a ble 3

Chlorides concentration in a dynamic leaching test for the fresh waste

\begin{tabular}{|c|c|c|}
\hline Sampling day & $\begin{array}{c}\text { Sample volume } \\
{\left[\mathrm{cm}^{3}\right]}\end{array}$ & $\begin{array}{c}\text { Chlorides concentration } \\
{\left[\mathrm{mg} / \mathrm{dm}^{3}\right]}\end{array}$ \\
\hline 8 & 50 & 106.34 \\
\hline 16 & 50 & 103.18 \\
\hline 24 & 50 & 77.99 \\
\hline 32 & 50 & 73.99 \\
\hline 40 & 50 & 71.99 \\
\hline 48 & 50 & 70.91 \\
\hline 56 & 50 & 62.39 \\
\hline 64 & 50 & 60.27 \\
\hline 72 & 50 & 58.14 \\
\hline 80 & 50 & 56.72 \\
\hline 92 & 75 & 55.31 \\
\hline 104 & 75 & 52.25 \\
\hline 116 & 75 & 51.05 \\
\hline 128 & 75 & 45.38 \\
\hline
\end{tabular}

Table 4

List of parameters characterizing the conditions

\begin{tabular}{|c|c|c|}
\hline \multirow[b]{2}{*}{ Parameters } & \multicolumn{2}{|c|}{ Sample } \\
\hline & $\begin{array}{l}15 \text { year old } \\
\text { waste }\end{array}$ & fresh waste \\
\hline The ratio of dry mass DR [\%] & 98.92 & 98.99 \\
\hline The ratio of moisture MC [\%] & 1.09 & 1.01 \\
\hline Mass of analytical sample $\mathrm{M}_{\mathrm{W}}[\mathrm{kg}]$ & 0.0910 & 0.0909 \\
\hline The volume of eluent $L\left[\mathrm{dm}^{3}\right]$ & 0.8990 & 0.8991 \\
\hline $\begin{array}{l}\text { Eluted mass of chloride ions } \\
\text { [mg/kg of dry mass] }\end{array}$ & $2.66 \cdot 10^{*}$ & $7.81 \cdot 10$ \\
\hline
\end{tabular}
of performing the static leaching tests
(according to the standard EN 12457-2)

* the concentration of chloride ions in the leachate $\left[\mathrm{mg} / \mathrm{dm}^{3}\right]$

concentration in the samples taken after 60 days did not exceed the limit of detection.

The initial weight of chlorides, which were subject to leaching, calculated on the basis the static tests, amounted to $26.6 \mathrm{mg} \mathrm{Cl} / \mathrm{kg}$ of dry matter in the 15 year old waste, and 78.1 $\mathrm{mg} \mathrm{Cl} / \mathrm{kg}$ of dry matter in the fresh waste (Table 4). Having carried out the measurements of the concentration of the analysed component at the flow rate $v=0.06 \mathrm{~cm} / \mathrm{d}$, and assuming that the content of the leached material was introduced at $x=0$, the transition curves in Figures 4 and 5 were obtained.

The obtained curves show particular concentrations of chlorides both in the old (Fig. 4) and the fresh samples (Fig. 5), while their expected values after the column experiment finished take into account previous values and the dispersion parameters. The curves indicate that the time needed to leach the chlorides from the analysed samples to a level near to 0 (according to calculations $\sim 0.5 \mathrm{mg} / \mathrm{dm}^{3}$ ) for the 15 year old waste and the fresh waste is 336 days and 830 days, respectively.

To relate the achieved results to the landfill body, the mean transit time of water was estimated in each column. The capacity of the column with the old waste was $918 \mathrm{~cm}^{3}$, whereas the capacity of the column with the fresh waste was $1.071 \mathrm{~cm}^{3}$. Taking into account the time necessary to fill the column, the vol- 


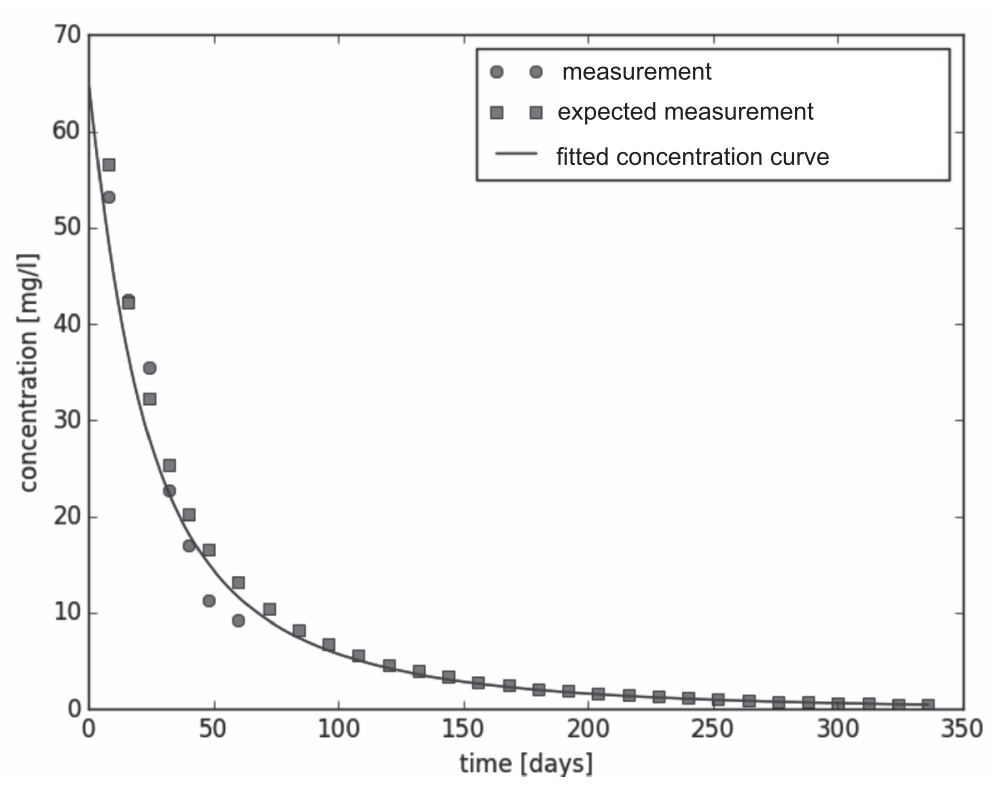

Fig. 4. Breakthrough curve of chlorides for the leaching tests from the 15 year old waste

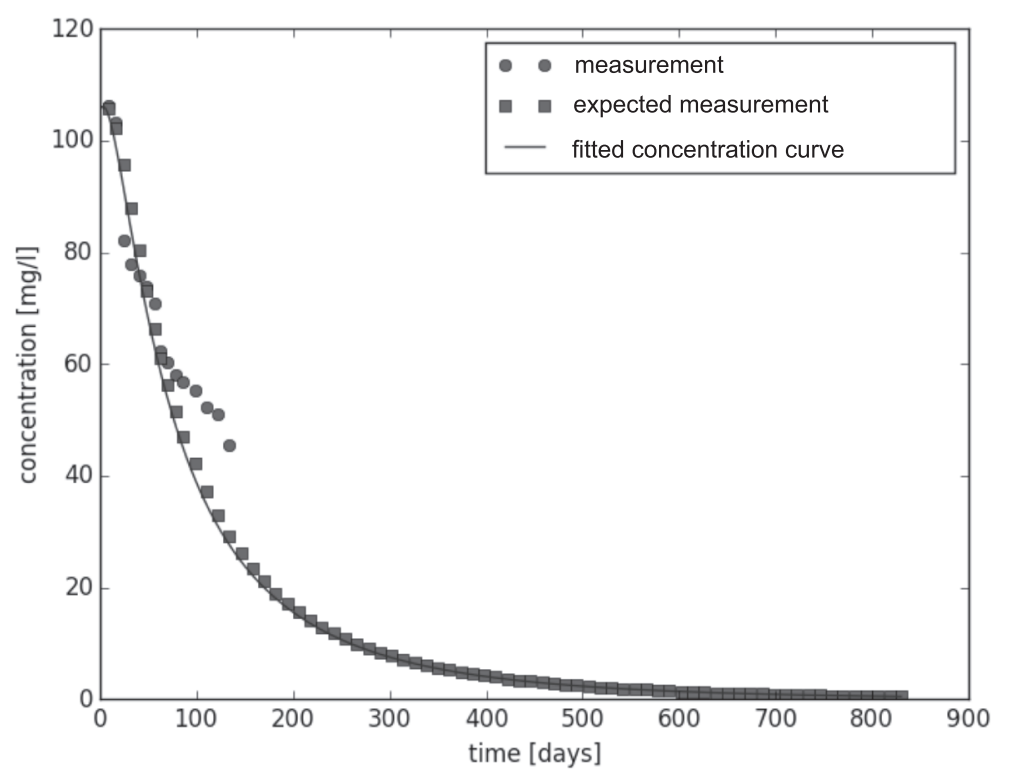

Fig. 5. Breakthrough curve of chlorides for the leaching tests from the fresh waste

ume of empty spaces, which corresponds to the open porosity, may be estimated with an accuracy of $50 \%$ in both of the experiments. Given that the efficiency of the pump supplying the column amounts to $6.24 \mathrm{~cm}^{3} / \mathrm{d}$, the mean transit time of water has been estimated at 73 days for the 15 year old waste and 86 days for the fresh waste.

Determining the mean transit time of water in the tested samples enabled the correlation of the results obtained in the experiment to the actual size of the landfill, for which it is also possible to estimate the time $\left(t_{R}\right)$, using the formula (Szczepańska, 1987):

$$
t_{R}=\frac{x}{u}
$$

where: $x-$ column length $(m)$; a landfill solid is equal to 2.5-32 (m); $u$ - groundwater flow velocity ( $\mathrm{m} / \mathrm{a})$.

Groundwater flow velocity is calculated using the formula:

$$
u=\frac{v}{n_{e}}
$$

where: $v$ - mean filtration velocity $(\mathrm{m} / \mathrm{a}) ; n_{e}$ - effective porosity coefficient; assumed to be 0.2 .

And finally:

$$
t_{R}=\frac{x \cdot n_{e}}{v}=\frac{V_{p}}{Q}
$$

where: $V_{p}$ - active pore volume per $1 \mathrm{~m}^{2}\left(\mathrm{~m}^{3}\right) ; \mathrm{Q}$ - flow rate per $1 \mathrm{~m}^{2}\left(\mathrm{~m}^{3} / \mathrm{a} \cdot \mathrm{m}^{2}\right)$, which, for the steelworks' landfill, is equal to $Q=0.7445\left(\mathrm{~m}^{3} / \mathrm{a} / \mathrm{m}^{2}\right) \cdot 0.3=0.223$ $\left(\mathrm{m}^{3} / \mathrm{a} / \mathrm{m}^{2}\right)$.

The value of $t_{R}$ depends on the thickness of the deposited waste: i.e., for a layer with a thickness of $2.5(\mathrm{~m}), V_{p}=\sim 0.5\left(\mathrm{~m}^{3}\right)$ and $t_{R}=2.24(\mathrm{a})$; whereas for a layer with a thickness of $32(\mathrm{~m}), V p=\sim 6.4\left(\mathrm{~m}^{3}\right)$ and $t_{R}=28.6(\mathrm{a})$. Taking into consideration the results of the dynamic tests, which show that $90 \%$ of chlorides were leached after reaching values of 2-3 for the mean transit time of water (Figs. 3 and 4), it can be assumed that a considerable leaching of chlorides from the landfill body will occur over a period of 60-90 years from the moment of depositing the waste. Thus, the waste landfill of the smelting plant will be the source of the groundwater contamination for several decades.

The time of the vertical seepage through the unsaturated zone beneath the landfill, estimated by the formula from Bachmat and Collins, in the outcrops of the Triassic formations, equals $\sim 2-3$ years, depending on the area of the landfill. Taking into account the hydrodynamic conditions and using Formula [10] for the flow rate $v$ :

$$
v=\frac{k \cdot l}{n_{e}}
$$

where: $k$ - permeability coefficient $=0.00011 \mathrm{~m} / \mathrm{s}$ (based on documentation from the piezometers); I - hydraulic gradient $=0.0035$ (based on a hydrogeological map); $n_{e}$ - effective porosity ( $=0.04$, according to Różkowski and Wilk, 1980).

It can be assumed that the time of the flow in the aquifer from the base of the landfill to the nearest piezometers ( $T 1$, T9) is $\sim 6-7$ months. The time it takes the waste contaminants to reach the piezometers is the total of the time of the vertical seepage through the landfill body and then through the unsaturated zone (2-3 years), and the time of the horizontal flow in the saturation zone from the landfill to the piezometers $(6-7$ months). Since the process of landfill formation is long-lasting, it is difficult to estimate the time of seepage through the landfill due to the changing thickness of the deposited waste. In the area of piezometers T1 and T9, where the waste has been de- 


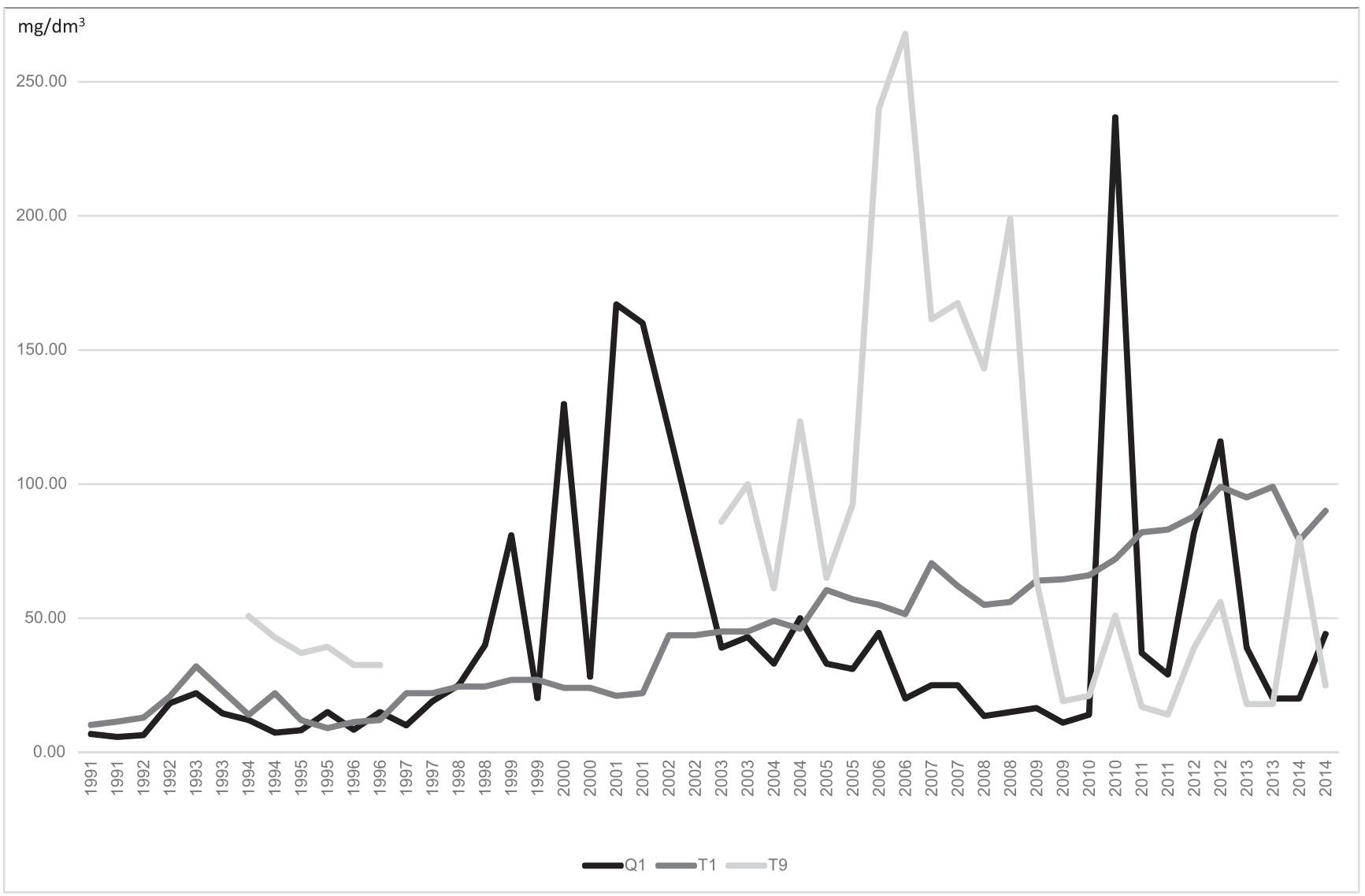

Fig. 6. The changes of chlorides concentration in groundwater from Q1, T1 and T9 piezometers

posited since $\sim 1989$, the landfill thickness exceeded $25 \mathrm{~m}$. Therefore, the first indications should have appeared in the piezometers $\sim 1992$. The analysis of the chlorides concentration in the most closely located piezometers shows that the first visible consequence of the impact of the deposited waste appeared in late 1992 and early 1993, when an increase in the chlorides concentration was observed (Fig. 6). In the case of the samples taken from piezometer $\mathrm{T} 1$, a temporary decrease in the concentration of this ion was followed by a regular increase from $\sim 10$ to $100 \mathrm{mg} / \mathrm{dm}^{3}$. When it comes to the nearby piezometer Q1, it was found that the chlorides concentration has risen since 1992/1993; however, the highest concentrations were recorded in the period 1998-2003. Since then, a fall in the concentrations has been observed. It may be assumed that the main impetus of the contaminants passed through the area of piezometer Q1 during this period. The occurrence of that impetus may be associated with the beginning of utilizing the material deposited in the landfill for the purpose of engineering works. A similar increase in concentration occurred in 2008 , i.e. at the time of landfill redevelopment (Dabrowska et al., 2015). The effects of the relocation and utilization of the waste from the smelting plant are visible in the samples from piezometer T9, which has not been sampled on such a regular basis as piezometers T1 and Q1. It is noticeable that, after 1994 , as in the case of the samples from piezometer T1, first there was a fall in the $\mathrm{Cl}$ concentration, followed by its rise in the period 2003-2010.
The evidenced increase in the chlorides concentration in piezometers Q1 and T1, which are located closest to the landfill of smelting plant waste, confirms both the high susceptibility of the groundwater to contamination and the activity of the landfill as a contamination source (Dabrowska et al., 2015).

Once the formula by Bachmat and Collins was tested in the landfill area, it was employed to perform calculations on the other known profiles. The achieved results also point to a short time for the seepage of water through the unsaturated zone. The time of seepage calculated for the Quaternary aquifer is 1-7 years, whereas, for the areas of outcrops of the Triassic carbonates, it amounts to 5-40 years (Fig. 7). In the majority of points, the vertical seepage time was shorter than 20 years; therefore, the objective area may be classified as an area of high groundwater protection.

\section{CHEMICAL COMPOSITION OF GROUNDWATER}

The presence of pollution found in the area of high groundwater vulnerability to contamination should result in a change in the chemical composition. To assess changes in the composition, the current chemical condition should be related to the chemical condition of the period preceding the construction of the industrial objects in the study area.

The characteristics of the chemical composition of groundwater in the Triassic carbonates of the studied region for the 


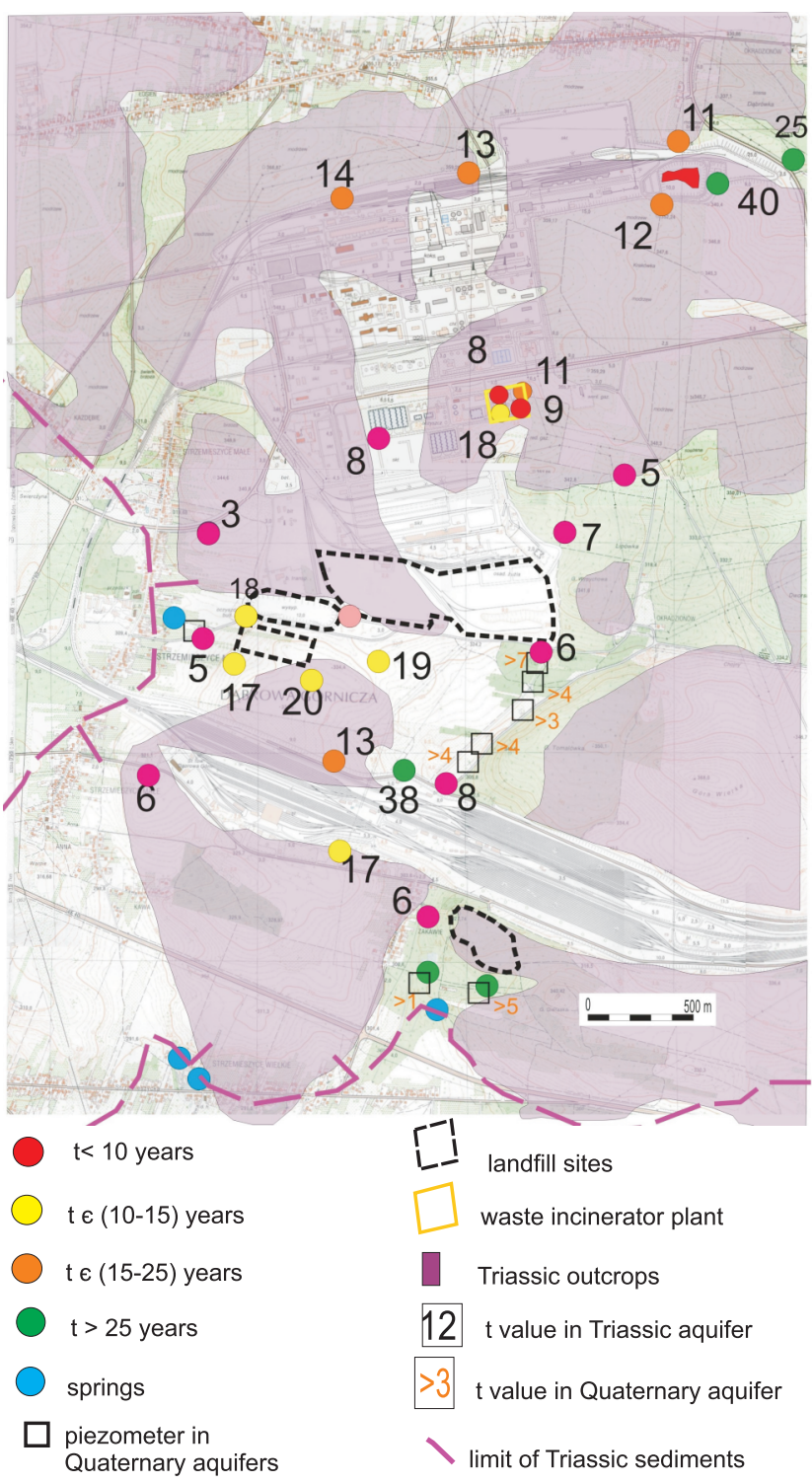

Fig. 7. Spatial distribution of the vertical seepage time $(t)$ 1960s can be found in Różkowska et al. (1975). The groundwater mineralisation in the Muschelkalk was $169-587 \mathrm{mg} / \mathrm{dm}^{3}$ (273 $\mathrm{mg} / \mathrm{dm}^{3}$ on average). The dominant types were $\mathrm{HCO}_{3}-\mathrm{Ca}$ and $\mathrm{HCO}_{3}-\mathrm{SO}_{4}-\mathrm{Ca}$. The content of anions was within the following limits: $\mathrm{HCO}_{3}-88-315 \mathrm{mg} / \mathrm{dm}^{3} ; \mathrm{SO}_{4}-8.6-195 \mathrm{mg} / \mathrm{dm}^{3} ; \mathrm{Cl}-$ 2.8-33 mg/dm ${ }^{3}$. As for the content of cations: $\mathrm{Ca}-17.2-98.6$ $\mathrm{mg} / \mathrm{dm}^{3} ; \mathrm{Mg}-2.4-50 \mathrm{mg} / \mathrm{dm}^{3} ; \mathrm{Na}+\mathrm{K}-2.3-6.9 \mathrm{mg} / \mathrm{dm}^{3}$. In $\sim 50 \%$ of the examined samples, the concentration of chlorides amounted to $5 \mathrm{mg} / \mathrm{dm}^{3}$, whereas that of sulphates was $25 \mathrm{mg} / \mathrm{dm}^{3}$. In $85 \%$ of the analysed water, the concentration of Ca was in the range of $20-70 \mathrm{mg} / \mathrm{dm}^{3}$, while that of $\mathrm{Mg}$ was up to $30 \mathrm{mg} / \mathrm{dm}^{3}$. In $>90 \%$ of the analysed material, the $\mathrm{Na}$ concentration did not exceed $10 \mathrm{mg} / \mathrm{dm}^{3}$. The average groundwater mineralisation in the Roet formations was $333 \mathrm{mg} / \mathrm{dm}^{3}$; these were $\mathrm{HCO}_{3}-\mathrm{Ca}-\mathrm{Mg}, \mathrm{HCO}_{3}-\mathrm{Ca}$ and $\mathrm{HCO}_{3}-\mathrm{SO}_{4}$-Ca-Mg waters. The concentration of $\mathrm{HCO}_{3}$ ions was $170-268 \mathrm{mg} / \mathrm{dm}^{3}$, $\mathrm{SO}_{4}$ ions $-18.2-67 \mathrm{mg} / \mathrm{dm}^{3}$, and $\mathrm{Cl}$ ions $-0.9-20 \mathrm{mg} / \mathrm{dm}^{3}$. The $\mathrm{Ca}, \mathrm{Mg}$ and $\mathrm{Na}$ concentrations were $36-63 \mathrm{mg} / \mathrm{dm}^{3}$, $10.2-33.9 \mathrm{mg} / \mathrm{dm}^{3}$ and $2.1-33 \mathrm{mg} / \mathrm{dm}^{3}$, respectively. The averaged chemical composition of the groundwater in the Triassic carbonates of the Muschelkalk and Roet in the 1960s is presented in Figure 8.

In order to determine the chemical condition of the groundwater in this area, in 2005 , samples were taken at accessible points of the local groundwater monitoring network. The average concentrations of major ions in the samples from 16 points in the Strzemieszyce area indicate that a significant change occurred in the chemical composition of the groundwater in comparison to the condition as of the 1960s. An increase in the concentration of virtually all major ions is noticeable (Fig. 8 and Table 5). A particularly significant increase is observed in the concentration of sulphate, chlorides, sodium and potassium, causing an increase in the average value of mineralisation (expressed in the amount of dissolved substances). In 2005, the $\mathrm{Na}$ and $\mathrm{Cl}$ concentrations in the groundwater locally exceeded $20 \%$ mval, which is unusual for this kind of aquifer.

The values presented in Table 5 were used to calculate the groundwater contamination index. The index enables unequivocal confirmation of the changes in the chemical composition of water. The most characteristic major ion, which illustrates the changes in the chemical composition of groundwater in the Triassic carbonates, is the chloride ion. In the 1960s, its concentration was $\sim 4-7 \mathrm{mg} / \mathrm{dm}^{3}$, whereas it is currently $\sim 7-10$ times

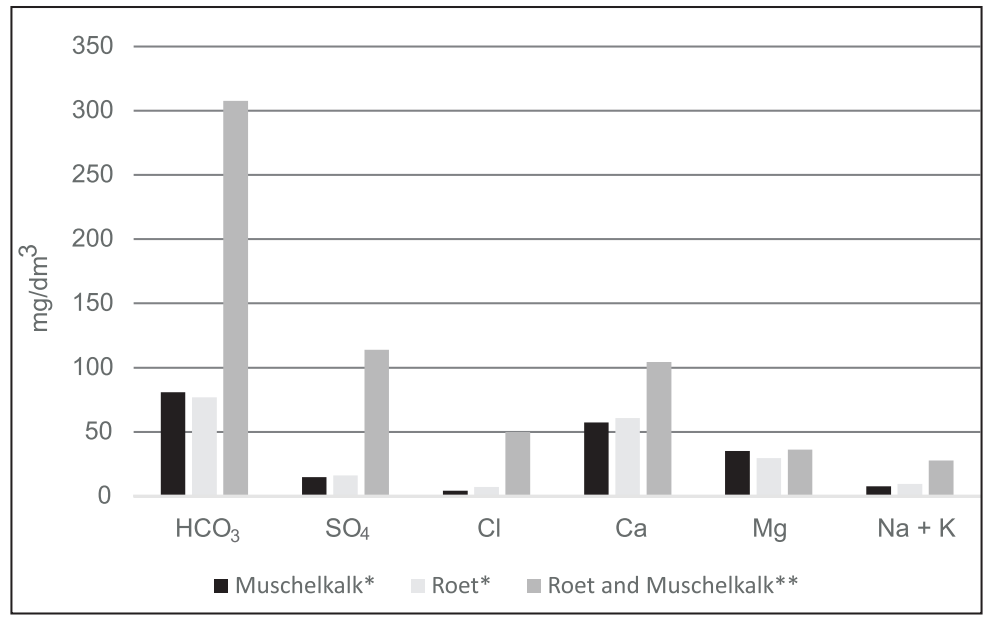

Fig. 8 Mean chemical composition of groundwater

* 1960s (based on Różkowska et al., 1972);

** 2005 (own research based on 16 chemical analyses) 
Basic statistics of groundwater chemical composition

\begin{tabular}{|c|c|c|c|c|c|c|c|c|}
\hline \multirow{2}{*}{$\begin{array}{c}\text { Aquifer } \\
\text { parameters }\end{array}$} & \multicolumn{4}{|c|}{ Triassic } & \multicolumn{4}{|c|}{ Quaternary } \\
\hline & $\mathrm{N}$ & $\min$ & $\max$ & mean & $\mathrm{N}$ & $\min$ & $\max$ & mean \\
\hline $\mathrm{pH}$ & 16 & 7.29 & 7.71 & 7.50 & 7 & 5.59 & 7.45 & 6.68 \\
\hline $\mathrm{EC}[\mu \mathrm{S} / \mathrm{cm}]$ & 16 & 554 & 1260 & 833.35 & 7 & 348.90 & 994.00 & 652.24 \\
\hline TDS [mg/l] & 16 & 420.20 & 819.50 & 596.65 & 7 & 245.70 & 801.70 & 477.39 \\
\hline $\mathrm{Ca}[\mathrm{mg} / \mathrm{l}]$ & 16 & 74.35 & 126.47 & 104.53 & 7 & 40.67 & 142.99 & 82.56 \\
\hline $\mathrm{Mg}[\mathrm{mg} / \mathrm{l}]$ & 16 & 27.15 & 46.26 & 36.28 & 7 & 13.11 & 49.99 & 27.28 \\
\hline $\mathrm{Na}[\mathrm{mg} / \mathrm{l}]$ & 16 & 2.22 & 100.07 & 24.77 & 7 & 3.15 & 76.56 & 18.36 \\
\hline $\mathrm{K}[\mathrm{mg} / \mathrm{l}]$ & 16 & 0.89 & 9.43 & 2.99 & 7 & 0.65 & 3.99 & 2.03 \\
\hline $\mathrm{NH}_{4}[\mathrm{mg} / \mathrm{l}]$ & 16 & 0.00 & 2.31 & 0.31 & 7 & 0.00 & 1.42 & 0.39 \\
\hline $\mathrm{Cl}$ [mg/l] & 16 & 9.58 & 189.67 & 50.09 & 7 & 7.03 & 62.60 & 27.70 \\
\hline $\mathrm{SO}_{4}[\mathrm{mg} / \mathrm{l}]$ & 16 & 81.28 & \begin{tabular}{|l|}
161.66 \\
\end{tabular} & 113.86 & 7 & 61.53 & 285.01 & 130.16 \\
\hline $\mathrm{NO}_{2}[\mathrm{mg} / \mathrm{l}]$ & 15 & 0.00 & 0.02 & 0.00 & 7 & 0.00 & 0.01 & 0.01 \\
\hline $\mathrm{NO}_{3}[\mathrm{mg} / \mathrm{l}]$ & 16 & 1.30 & 52.00 & 31.78 & 7 & 3.00 & 68.00 & 22.43 \\
\hline $\mathrm{HCO}_{3}[\mathrm{mg} / \mathrm{l}]$ & 16 & 253.22 & 408.81 & 307.56 & 7 & 21.36 & 512.54 & 200.92 \\
\hline
\end{tabular}

higher. The spatial distribution of the contamination index calculated for chlorides is shown in Figure 9. The highest values were recorded in the area of the SARPI incinerator and the unprotected landfill of ArcelorMittal waste.

Given the high groundwater mineralisation in the area of the landfills, the contamination index for the major ions was calculated. The obtained spatial distribution was similar to results obtained for chlorides, i.e. the highest values (47) were characteristic of the water collected in the area of the waste incinerators and landfills for the ArcelorMittal smelting plant in Zakawie, as well as in the vicinity of the municipal landfills (Fig. 10).

The contamination index value decreases with the increasing distance from the aforementioned objects. In the majority of points, the value exceeds 3 , which, in accordance with the applicable criteria (Backman et al., 1998), indicates a high threat to groundwater in the area.

\section{SUMMARY AND CONCLUSIONS}

This study has confirmed that the Strzemieszyce area is characterized by a high vulnerability to groundwater contamination. This is reflected by the short seepage time from the surface to the water table. It was estimated at some points even at only 3 years. High vulnerability to pollution in this area is due to the lack of isolation of aquifer. The aquifer is associated with Triassic carbonates that crop out in the Strzemieszyce area.

The study area is located in the supply zone of the OlkuszZawiercie Major Groundwater Reservoir. Therefore, from the point of view of groundwater protection, the site use should not cause any danger to the quality of the reservoir waters. However, the unfortunate location of industrial facilities has led to significant changes in the chemical composition of groundwater, which is confirmed by the high value of the contamination index.

Taking into account the chemical background for $\mathrm{Cl}, \mathrm{SO}_{4}$, $\mathrm{HCO}_{3}, \mathrm{Ca}, \mathrm{Mg}$ and $\mathrm{Na}+\mathrm{K}$ the contamination index value ranges from 5 to 47 , which is characteristic for strongly transformed waters.

A characteristic indicator of changes in chemical composition is the concentration of chlorides, which was $4.32-7.10 \mathrm{mg} / \mathrm{l}$ on average before the start of the investment, and, according to

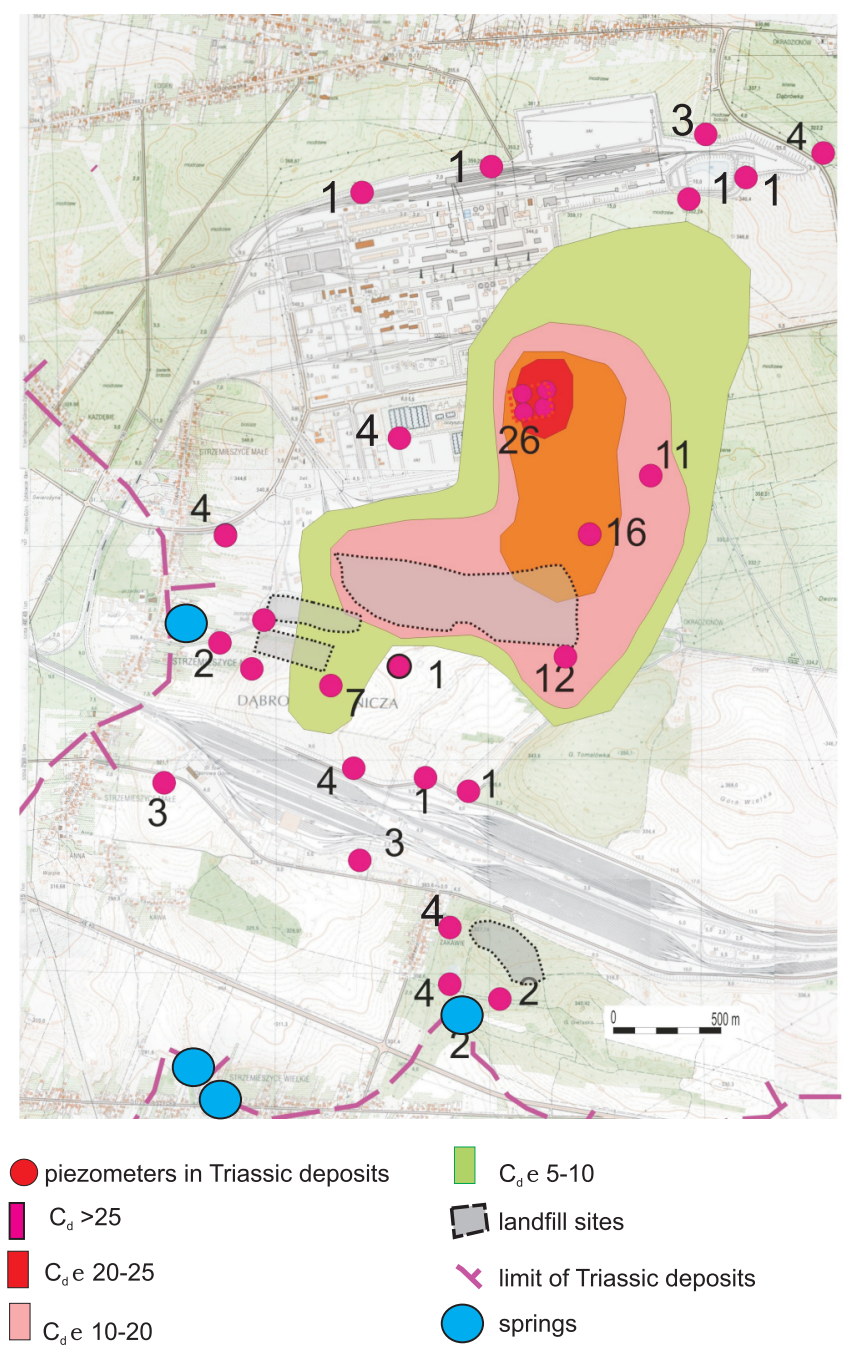

Fig. 9. Spatial distribution of the contamination index $\left(C_{d}\right)$ of groundwater for chlorides in the Triassic carbonates 


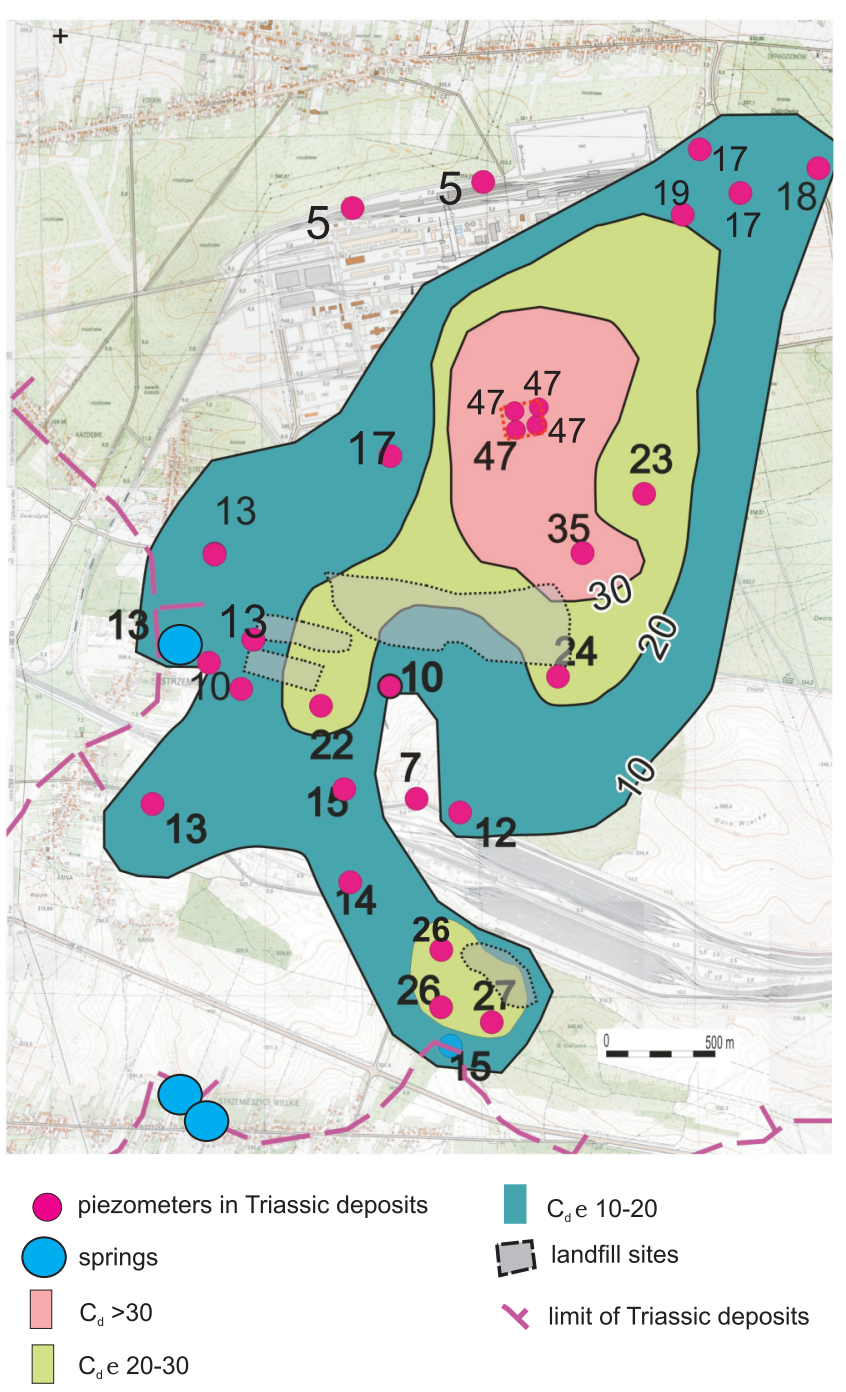

Fig. 10. Spatial distribution of the contamination index value $\left(C_{d}\right)$ of groundwater for major ions the current data, it ranges from 9.60 to $189.70 \mathrm{mg} / \mathrm{l}$, averaging $50.10 \mathrm{mg} / \mathrm{l}$. Because of the carbonate type of the aquifer, anthropopressure could be the only cause of the increased chloride concentrations.

The results of the monitoring studies carried out in 2005 confirmed the change in the chemical composition of the groundwater in the area, which must be associated with the impact of the industrial facilities. The most dramatic changes in the chemical composition have taken place in the vicinity of the SARPI incinerator. A high impact on the groundwater has also been exerted by the waste landfill of the ArcelorMittal smelting plant. This landfill, which covers 45 ha, has no liner system.

The dynamic leaching tests and mathematical modelling of the obtained results allowed us to determine the time of leaching of chlorides from metallurgical slags. The satisfactory results for a few-day-old slag, confirmed by the model's compatibility with the experimental data for the 15 year old slag, were obtained using the minimizing L-BFGS method. Conversion of the leaching intensity on a number of water exchanges in the column allowed us to relate these results to the solid of landfill. The mean transit time of water through the landfill has been estimated at 2.2 to 28.6 years depending on the thickness of the waste layer. Therefore it can be assumed that a considerable leaching time of chlorides from the o landfill body will occur over a period of $\sim 60-90$ years from the moment of depositing the waste. Components subjected to sorption or resulting from weathering will be leaching much longer.

The results indicate that groundwater pollution has already been present. This fact should be taken into account as regards the industrial activity in this area. Being aware that existing facilities have an impact on the groundwater, industrial activity should be conducted in such a way as to eliminate the possibility of major industrial accidents, to limit, even gradually, existing impacts, and to equip any new facility with systems that eliminate groundwater contamination.

This approach will be developed by estimating the leaching time of other physicochemical parameters from the solids of waste, while the proposed method can be used especially for groundwater vulnerability assessments in industrialized areas.

Acknowledgements. We greatly appreciate the reviewers (T. Nałęcz and two anonymous) for their helpful comments and suggestions.

\section{REFERENCES}

Alexandrowicz, S., Alexandrowicz, Z., 1960. Triassic sediments in the vicinity of Strzemieszyce and Sławków (Upper Silesia) (in Polish with English summary). Biuletyn Instytutu Geologicznego, 152: 95-171.

Backman, B., Bodis, D., Lahermo, P., Rapant, S., Tarvainen, T., 1998. Application of a contamination index in Finland and Slovakia. Environmental Geology, 36: 55-64.

Bhuiyan, M., Bodrud-Doza, M., Islam, A., Rakib, M., Rahman, M., Ramanthan, A., 2016. Assessment of groundwater quality of Lakshimpur district of Bangladesh using water quality indices, geostatistical methods and multivariate analysis. Environmental Earth Sciences, 75, 10.1007/s12665-016-5823-y.

Bielewicz, R., Suszka, G., Sztembis-Bukowska, A., 2010. Baza danych GIS Mapy hydrogeologicznej Polski 1:50 000. Pierwszy poziom wodonośny, wrażliwość na zanieczyszczenie. Arkusz Zawiercie (in Polish). Polish Geological Institute - National Research Institute.

Boufekane, A., Saighi, O., 2013. Assessment of groundwater pollution by nitrates using intrinsic vulnerability methods: a case study of the Nil valley groundwater (Jijel, North-East Algeria). African Journal of Environmental Science and Technology, 7: 949-960.

Brown, K., Donnelly, K., 2009. An estimation of the risk associated with the organic constituents of hazardous and municipal waste landfill leachates. Environmental Engineering Sciences, 5: 1-30.

Civita, M., 2010. The combined approach when assessing and mapping groundwater vulnerability to contamination. Water Resources Protection, 2: 14-28. 
Dąbrowska, D., Sołtysiak, M., Kucharski, R., 2015. The homogeneity of the groundwater monitoring network in the region of the landfills' system in Strzemieszyce (in Polish with English summary). Przegląd Geologiczny, 63: 657-660.

Fetter, C., 2001. Applied Hydrogeology. Prentice Hall. Upper Saddle River. Pearson.

Foster, S., 1987. Fundamental concepts in aquifer vulnerability, pollution risk and protection strategy. Intern. Conf. Vulnerability of Soil and Groundwater to Pollutants, RIVM Proceedings, 38: 69-86.

Gogu, R., Dassargues, A., 2000. Current trends and future challenges in groundwater vulnerability assessment using overlay and index methods. Environmental Geology, 39: 549-559.

Goldscheider, N., 2003. The PI Method. In: Cost Action 620 - Vulnerability and risk mapping for the protection of carbonate (karst) aquifers (ed. F. Zwahlen): 144-154. Final report. European Commission Directorate General for Research.

Gomo, M., Masemola, E., 2016. Groundwater hydrogeochemical characteristics in rehabilitated coalmine spoils. Journal of African Earth Sciences, 116: 114-126.

Hermanowski, P., Ignaszak, T., 2017. Ground water vulnerability based on four different assessment methods and their quantitative comparison in a typical North European Lowland river catchment (the Pliszka River catchment, western Poland). Geological Quarterly, 61 (1): 166-176.

Kabbour, B., Zouhri, L., Mainia, J., Colbeaux, J., 2006. Assessing groundwater contamination risk using the DASTI/IDRISI GIS method: coastal system of western Mamora, Morocco. Bulletin of Engineering Geology and Environment, 65: 463-470.

Krogulec, E., 2004. Vulnerability groundwater assessment in the river valley based on the hydrodynamic evidence (in Polish with English summary). University of Warsaw, Warsaw.

Krogulec, E., 2011. Intrinsic and specific vulnerability of groundwater to contamination in a river valley (in Polish with English summary). Biuletyn Państwowego Instytutu Geologicznego, 445: 337-344.

Lambrakis, N., Anatonakos, A., Panagopoulos, G., 2004. The use of multi component statistical analysis in hydrogeological environmental research. Water Research, 38: 1862-1872.

Leibundgut, C., Małoszewski, P., Külls, Ch., 2009. Tracers in hydrology. Wiley-Blackwell, Chichester.

Liu, L., Cheng, S., Guo, H., 2004. A simulation-assessment modeling approach for analyzing environmental risks of groundwater contamination at waste landfill sites. Human and Ecological Risk Assessment, 10: 373-388.

Nourani, V., Ejlali, R., Alami, M., 2011. Spatiotemporal groundwater level forecasting in coastal aquifers by hybrid artificial neural network-geostatistics model: a case study. Environmental Engineering Sciences, 28: 217-228.

Nourani, V., Khanghah, T., Sayyadi, M., 2013. Application of the Artificial Neural Network to monitor the quality of treated water. International Journal of Management and Information Technology, 3: 38-45.

Nourani, V., Andalib, G., Dąbrowska, D., 2017a. Conjunction of wavelet transform and SOM-mutual information data pre-processing approach for Al-based Multi-Station nitrate modeling of watersheds. Journal of Hydrology, 548: 170-183.

Nourani, V., Mousavi, S., Dąbrowska, D., Sadikoglu, F., 2017b. Conjunction of radial basis function interpolator and artificial intelligence models for time-space modeling of contaminant transport in porous media. Journal of Hydrology, 548: 569-587.

Oke, S., Vermeulen, D., Gomo, M., 2016. Aquifer vulnerability assessment of the Dahomey Basin using the RTt method. Environmental Earth Sciences, 75: 1-9.

Panagopoulos, G., Anatonakos, K., Lambrakis, N., 2006. Optimization of the DRASTIC method for groundwater vulnerability assessment via the use of simple statistical methods and GIS. Hydrogeology Journal, 14: 894-911.
Pazdro, Z., 1983. Hydrogeologia (in Polish). Wyd. Geol., Warszawa.

Priddle, M.W., Jackson, R.E., 1991. Laboratory column test measurement of VOC retardation factors and comparison with field values. Groundwater, 29: 260-266.

Robins, N.S., 1998. Groundwater pollution, aquifer recharge and vulnerability. Geological Society Special Publications, 130.

Różkowska, A., Różkowski, A., Rudzińska, T., 1975. Hydrochemical characteristics of the Triassic water-bearing system in the Silesia-Cracow region (in Polish with English summary). Biuletyn Instytutu Geologicznego, 282: 579-581.

Różkowski, A., 1990. Szczelinowo-krasowe zbiorniki wód podziemnych Monokliny Śląsko-Krakowskiej i problemy ich ochrony (in Polish). SGGW-AR Press, Warszawa.

Różkowski, A., Wilk, Z., 1980. Warunki hydrogeologiczne złóż rud cynku i ołowiu regionu śląsko-krakowskiego (in Polish). Instytut Geologiczny, Warszawa.

Różkowski, A., Rudzińska, T., Siemiński, A., 1997. Mapa warunków występowania, użytkowania, zagrożenia i ochrony zwykłych wód podziemnych GZW i jego obrzeżenia, 1:100 000 (in Polish). Państwowy Instytut Geologiczny, Warszawa.

Singh, P., Verma, P., Tiwari, A., Sharma, S., Purty, P., 2015. Review of various contamination index approaches to evaluate groundwater quality with Geographic Information System (GIS). International Journal of ChemTech Research, 7: 1920-1929.

Sołtysiak, M., 2007. The Lysimeter research of leaching from metallurgical slags of the Katowice Steelwork (in Polish with English summary). In: AGH, Współczesne problemy hydrogeologii, 13 (2): 345-353. Kraków.

Sołtysiak, M., 2009. The dynamic tests of leaching from metallurgical slags of the Katowice Steelwork (in Polish with English summary). Biuletyn Państwowego Instytutu Geologicznego, 436: 475-482.

Stupnicka, E., 2007. Geologia regionalna Polski (in Polish). Warsaw University Press.

Szczepańska, J., 1987. Coal waste as a source of pollution of the aquatic environment (in Polish with English summary). Scientific Bulletins of Stanisław Staszic Academy of Mining and Metallurgy 1135. Geology, 35.

Todd, D., Mays, L., 2005. Groundwater Hydrology. Wiley.

Troiano, J., Spurlock, F., Marade, J., 1999. Update of the California Vulnerability Soil Analysis for Movement of Pesticides to Groundwater. Department of Pesticide Regulation.

Vrba, J., Zaporozec, A. eds., 1994. Guidebook on mapping groundwater vulnerability. IAH International Contributions to Hydrogeology, 16.

Wachniew, P., Zurek, A., Stumpp, C., Gemitzi, A., Gargini, A., Filippini, M., Rozanski, K., Meeks, J., Kvaener, J., Witczak, S., 2016. Towards operational methods for the assessment of intrinsic groundwater vulnerability: a review. Critical Reviews in Environmental Science and Technology, 46: 827-884.

Wang, X., Li, H., Yang, J., Wan, L., Wang, X., Jiang, X., Guo, H., 2014. Measuring in situ vertical hydraulic conductivity in tidal environments. Advances in Water Resources, 70: 118-130.

Witczak, S., Żurek, A., 1994. The use of soil-agricultural maps in evaluating the protective role of soils for groundwater (in Polish with English summary). In: Methodical Basement of the Groundwater Protection (ed. A.S. Kleczkowski ). AGH University of Science and Technology, Cracow.

Witkowski, A., Kowalczyk, A., 2004. A simplified method of regional groundwater vulnerability assessment. International Conference on Groundwater Vulnerability Assessment and Mapping, Ustroń, Poland.

Witkowski, A., Rubin, K., Kowalczyk, A., Różkowski, A., Wróbel, J., 2003. Groundwater vulnerability map of the Chrzanów karst-fissured Triassic aquifer (Poland). Environmental Geology, 4: 59-67.

Yang, Y.S., Wang, L., 2010. Catchment-scale vulnerability assessment of groundwater pollution from diffuse sources using the 
DRASTIC method: a case study. Journal of Hydrological Sciences, 55: 1206-1216.

Zhang, Ch., Li, Ch., Huang, Y., 2009. A new method applied for the evaluation of municipal solid waste landfill stabilization. Environmental Engineering Sciences, 26: 1123-1130.

Zhu, C., Byrd, R., Lu, P., Nocedal, J., 1997. L-BFGS-B: algorithm 778: L-BFGS-B, FORTRAN routines for large scale bound constrained optimization. ACM Transactions on Mathematical Software, 23: 550-560.

Zuber, A., 1984. Review of existing mathematical models for interpretation of tracer data in hydrology. Proc. of an Advisory Group
Meeting and Mathematical Models Interpretation of Tracer Data, IAEA.

Zwahlen, F., 2004. Vulnerability and risk mapping for the protection of carbonate (karst) aquifers, final report COST action 620. European Commission, Directorate-General for Research, EUR 20912:297.

EN 12457-2 Characterisation of waste - Leaching - Compliance test for leaching of granular waste materials and sludges - Part 4: One stage batch test at a liquid to solid ratio of $10 \mathrm{l} / \mathrm{kg}$ for materials with particle size $<10 \mathrm{~mm}$ (without or with size reduction). 